[Accepted for European Political Science, special issue December 2016]

\title{
Organising for a more diverse political science: Australia and New
} Zealand

Marian Sawer, Australian National University and Jennifer Curtin, University of Auckland

\section{Abstract}

Until the 1970s neither Australian nor New Zealand political studies gave much attention to issues of diversity. This reflected both the makeup of the profession and the majoritarian nature of the political system that was the major object of its attention. We argue that feminist organising on both sides of the Tasman had led to greater pluralism within the discipline. Using a comparative institutional approach, we trace the relationship between organising within the professional associations and the acceptance of greater diversity of approach and standpoint. We find, however, that while both countries' Associations have become somewhat more inclusive, a hierarchy of knowledge still exists that may prove an obstacle to feminist and Indigenous political scientists joining discipline-based departments and programs.

Keywords: diversity, gender, political science discipline, Australia, New Zealand

'...gender remained a characteristic reserved for women...'

'...politics departments may be culturally chilly for Indigenous peoples.'

\section{Introduction}

The arrival of the second wave of the women's movement in Australia and New Zealand posed a significant challenge to political science as it was then constituted. The women's movement was reframing the subject of politics to encompass what was 
previously excluded but was now seen as a primary locus of women's subjugation, the realm of the 'private' in contrast to the 'public'. As part of extending political analysis to the 'private' realm, the women's movement was problematising the absence of women from the public realm. Previously the absence of women from public decision-making had scarcely been noticed. If noticed, it was regarded as part of a natural division of labour whereby the primary role of women lay within the family, not with political careers or public life. Failure to notice the absence of women from politics is perhaps not so surprising given the composition of the political science profession of the time. But it was not only women who were missing from politics and its study - until the 1970s the absence of Indigenous people was also taken for granted, in Australia particularly, as was the absence of other forms of diversity.

Assumptions that the absence of women from politics was part of natural order came under radical challenge in the 1970s. The women's movement began demanding that women should 'make policy, not tea'. Instead of accepting that women's family roles precluded serious political careers, there were new critiques of the masculine bias of political institutions and also of the way that political science took male politics as the norm. Feminist writing reframed the issue of women's political participation not as one of female deficits but of exclusionary institutions and 'sexist scientism' (Goot and Reid, 1975).

These critiques suggested that women's absence from politics was due not to their domestic priorities, but to the failure of political institutions to accommodate the realities of their lives. Such critiques of exclusionary institutions were soon to be 
voiced by activists from other groups seeking equal citizenship, not only Indigenous groups but also, for example, people with disabilities.

This article builds on earlier disciplinary histories in Australia and New Zealand that have examined the status of women in the profession; the integration of gendered approaches and feminist scholarship into the curriculum and the integration of Indigenous politics and scholarship (Sawer, 2004; Chappell \& Brennan, 2009; Curtin, 2013; Curtin, 2015; Curtin, 2016; Johnson, 2014; Johnson, 2015b; Rowse 2009; Sanders 2015). In doing so, we adopt a comparative institutional approach to explore the relationship between feminist organising and greater reflexivity and diversity within the discipline. However, given there have been considerable connections between the Australian and New Zealand political science professions, in terms of Association membership, conference attendance and policy transfer, this study represents a most-similar comparative project.

The Australian Political Studies Association (APSA, founded in 1951) became the Australasian Association in 1965, to signal that it encompassed New Zealand, but in 2007 it controversially decided to end the New Zealand connection and became the Australian Political Studies Association again. In the meantime, New Zealand had established its own relatively small Political Studies Association (NZPSA) in 1974.

Women's caucuses were established in both the Australian and New Zealand Associations to promote the status of women and a more gender-inclusive discipline, albeit several years apart. In this article we provide case studies of the activity of these caucuses in the two countries, comparing repertoire and outcomes. We then 
provide a comparative study of the inclusion of Indigenous themes and scholarship within the discipline. We conclude that while space has been made for more diverse scholarship and chapters added to textbooks and disciplinary histories, the approach remains additive rather than transformative.

\section{Gendering political science in Australia}

In Australia the federal election of 1972 saw both the election of a reforming government and the successful placement of women's movement demands on the public policy agenda. Women's Electoral Lobby (WEL) had been formed to do a candidate survey similar to one recently done of presidential candidates in the US. WEL was highly successful in getting commitments on its issues from the incoming government. Although political scientists had largely shared the assumptions of politicians that questions concerning reproduction and childcare were not part of the proper subject of politics, at least one prominent political scientist was quick to notice that the women's movement was expanding the electoral agenda.

Professor Henry Mayer of the Department of Government at the University of Sydney, one of the 'founding fathers' of the Australian political science profession, included six articles by WEL members in his book of the 1972 federal election (for example, Glezer et al 1973). Mayer was Editor of Politics, the APSA journal, and the November 1973 issue also featured a debate by activists and academics over feminist conceptions of power. On top of his role in introducing feminist frames of reference into Australian political science, Mayer was supervising a $\mathrm{PhD}$ thesis that became the ground-breaking feminist history, Damned Whores and God's Police (Summers 1975; 1994; 2002). In the midst of writing this thesis Summers co-founded Australia's first 
women's refuge.

Despite the enthusiasm of individuals such as Mayer, gender subordination fell outside the narrow conceptions of the 'political' generally found in political science. The problem was partly that this new research was multi-disciplinary or transgressed disciplinary boundaries. At the University of Sydney the course taught by Carole Pateman in the late 1970s was called 'the Political Economy of Women'; it drew on both a number of social science disciplines and on feminist activists who presented 'how to' lectures.

Henry Mayer's reflexivity about his own behaviour (he began washing the dishes as a result of exposure to women's movement ideas) ${ }^{1}$ was exceptional at a time when political science, like politics, was still generally a ‘two-person’ career. A political scientist needed a wife who not only took care of home and family, but also contributed to her husband's output in a myriad of other ways. There was a standard acknowledgement that appeared in the preface of political science books along the following lines:

Finally, but far from least importantly, I must thank my wife...who, among other things, typed numerous drafts of the manuscript both cheerfully and without pay. My work resulted in demands on her time and energy which it was sometimes easy to overlook, because of the automatic way she accepted the responsibilities and commitments involved (Brown 1983: vii).

\footnotetext{
${ }^{1}$ As attested by Mayer's widow (Wilson 2006: 5).
} 
The image of the political scientist's wife cheerfully typing the numerous drafts of her husband's manuscript, summons up the image of the politician's wife, the smiling fixture standing by his side. The 'two-person career' in political science meant that the two-person career in politics was taken for granted until the arrival of feminist critique, rather than subjected to critical analysis.

Few senior political scientists were immediately receptive to feminist critique of 'twoperson careers' or the 'incorporated wife', whether that critique was applied to study of pathways to parliament or their own professional practice. In declaring 'the personal is the political' feminist research was moving into uncomfortable areas. Inspired by women's movement deconstruction of received wisdom, feminist scholars disputed claims of the political science discipline to be value-free.

Feminist political scientists writing in the 1970s and 1980s were clear that it was the women's movement that was the source of their critique of the discipline as well as providing an organisational philosophy. Those inspired by the women's movement brought collectivist practices and a feminist agenda into the political science professions and even into scholarly publishing (Sawer 2014: 139). Women’s caucuses were established in the American Political Science Association in 1969, followed by the United Kingdom in 1977, Canada in 1978 and Australia in 1979.

The Women's Caucus of the then Australasian Political Studies Association was cofounded by Carole Pateman and Marian Sawer. Like its overseas models it had the twin aims of improving the status of women in the profession and making women visible in the political system and in the political science curriculum. A survey 
conducted at the time found that while women were well-represented in non-tenured political science positions such as tutor, holding almost 40 per cent of positions, they held only 11 per cent of tenured or tenurable positions. The most common pattern was the presence of one woman on the tenured or tenurable staff, regardless of departmental size (Sawer, 1980). This survey was the first of many audits undertaken or initiated by the Women's Caucus.

The establishment of the Caucus also ensured that an executive slate was quickly altered to enable Carole Pateman to become APSA President in 1980. In her historic presidential address she spoke of the general failure of academic political studies to see 'that the political status of women poses a problem'. She said that although women were now more likely to be mentioned: 'That we are less than full members in political life is still regarded as unremarkable’ (Pateman, 1982: 3; Johnson, 2014: 122; Johnson, 2015: 697-8). Pateman went on to become the first woman president of the International Political Science Association, where she introduced important reforms to increase the representation of women. ${ }^{2}$

Over its 25 years of existence the Women's Caucus has taken the initiative in ensuring repeated audits of the status of women in the profession and attention to a range of equal opportunity issues. The proportion of women in tenured positions rose from 11 per cent in 1979 to almost 30 per cent in 1998. However, it then plateaued and was still at 28 per cent in November 2010, despite a continuing rise in the proportion of women among PhD students (Cowden et al., 2012: 15-16). The continuing rise in women $\mathrm{PhD}$ students (from 28 per cent in 1979 to 38 per cent in

2 Later Pateman became the seventh woman to be president of the American Political Science Association (2010). 
1998 and 47 per cent by 2010 meant a deterioration in the ratio of women staff to students. The leakage of women from the profession was most noticeable at the point of completion of doctoral studies (Cowden et al, 2012: 19). To maintain attention to such issues, the Women's Caucus has been responsible for a significant increase of women on the APSA Executive over time, including since 1992 a Women’s Caucus representative who holds an ex officio position. It has also strongly supported the convention of alternation of men and women as APSA presidents, adopted in 1998.

In 2011 APSA funded a highly successful workshop on The Advancement of Women in Australian Political Science. The Report of the Workshop drew attention to the ‘chilly climate’ created in a number of political science departments by adversarial norms of behavior and a lack of respect for a plurality of approaches within the discipline. Many workshop participants reported how 'the gendering of elite and 'hard' knowledge supported, and was reinforced by, antagonistic and disrespectful behaviour' (Cowden et al., 2012: 22). For example, in one department, seminars were experienced as ‘unsafe space' or even like witnessing a 'gang bang' (group rape). As Latin American scholars working in Australia later wrote, the 'seemingly simple act of revealing the speaking subject (I) behind the production of knowledge required overcoming the fear of breaking disciplinary rules of conduct and putting at risk academic recognition by potential peers‘ (Arashiro \& Barahona, 2015: vii).

APSA responded positively to many of the recommendations of the workshop, which included annual awards for inclusive and collaborative leadership in political science. APSA accepted this recommendation and the first four Academic Leadership in Political Science Awards were presented at the 2015 Annual Conference, in 
recognition of work to support pluralism and collegiality.

Since its creation the APSA Women's Caucus has advocated a more inclusive discipline and one that respects a plurality of approaches. This work has taken a number of forms: iterative surveys of textbooks and curriculum; surveys of journal content; sponsorship of gender (later gender and sexuality) streams at the annual APSA conferences; initiation of prizes for gender scholarship and for integration of gender and feminist perspectives into political science.

In 1981 the Women's Caucus passed a successful motion to make gender-inclusive curriculum an official APSA policy; subsequently it has conducted a number of surveys of both curriculum and text books to examine implementation of this policy. Successive surveys found an increasing tendency to include a chapter on women or gender in textbooks, perhaps in response to a previous survey, but for the other chapters to ignore feminist or gender scholarship. Moreover gender remained a characteristic reserved for women and was 'not considered part of the overall construction of political life’ (Sawer, 2004: 559).

Attention also turned to the APSA journal. An initial survey of its content, conducted in 1979, was followed by a survey covering the period 1979-98 (Curtin et al., 1999). The latter survey found that although there had been an increase in material by and about women in the period following the first survey, this progress was short-lived and subsequent patterns were variable. The 1998 review again had a salutary effect, with articles by women increasing from 18.8 per cent of the total in 1996-98 to 31.5 per cent in 2000-2004 (McAllister 2006: 4) and a gender audit becoming a regular 
feature of the Editor's annual report. A more recent review, prepared by a longstanding Women's Caucus member for the $50^{\text {th }}$ anniversary of the journal, found that over 80 articles on the broad topics of women, gender and feminism had been published between 1966 and 2015, ranging from quantitative and qualitative election studies to political economy, discourse analysis and new institutionalist approaches to public policy. Only two of the articles however, engaged with issues of masculinity and gender performance by male political leaders (Johnson, 2015b: 702).

From its formation, the Women's Caucus ensured the presentation of gender scholarship at the annual APSA conference through sponsoring a stream for this purpose: variously called the Women's Caucus stream, gender politics, feminist politics and gender and sexuality. This paved the way for recognition of other forms of diversity, such as a stream on Indigenous politics. Continuing vigilance was required, with the gender stream disappearing from two successive conferences in 2013 and 2014, a matter then addressed by the APSA Executive.

To draw attention to quality gender scholarship, the Women's Caucus introduced a women and politics prize as early as 1981. This was at first an annual, then biennial prize, for best unpublished article-length work. While the idea of competitive prizes was somewhat controversial given the feminist stress on collectivity and collaboration rather than individual competition, it was deemed worthwhile to give visibility to feminist scholarship and ensure that more of it appeared in the APSA journal.

A more recent innovation has been the introduction of the Carole Pateman book prize, to be awarded in alternate years to the Women and Politics Prize, for the book that 
best integrates gender and feminist scholarship into political science. It was first awarded in 2015 for The Political Economy of Violence against Women (True, 2013). Both prizes are open to either men or women, with the first being restricted to students based in Australia or New Zealand and the second restricted to members of APSA. Details of these activities and other relevant information can most readily be found on the Women's Caucus Facebook page. ${ }^{3}$ In 2016 APSA also provided funding for a workshop on gendered innovation in political science, to draw attention to areas in which gender and feminist scholarship has enriched the discipline and sharpened its focus.

While the proportion of women in the Australian political science discipline has remained largely the same over the past decade, there are considerably more women at senior levels than a generation ago, occupying 27 per cent of political science chairs (full professorships) and 31 per cent of international relations chairs in February 2016 (see Table 1). This is a considerable advance over the one woman chair found in the 1998 survey. However, it is the organised and collective presence of women in the Association that has kept issues of gender equity and diversity on the agenda. New challenges have arisen with the adoption of new forms of research governance and quality assessment to identify and reward research 'excellence'. There has been less awareness than in Europe of how gender bias influences decisions on what constitutes 'excellence' and how new research quality frameworks may reinforce existing and highly gendered hierarchies of knowledge (Johnson, 2014: 127-128). The context-rich discursive and institutional approaches adopted by many women tend to be devalued relative to more abstract quantitative or model-building

\footnotetext{
${ }^{3}$ https://www.facebook.com/ApsaWomensCaucus
} 
work favoured by the highest-ranking American journals. In Australia, as in the UK, scholars are rewarded for publishing 'far from home' and problem-oriented research embedded in detailed knowledge of local institutions and politics is often at a discount (Foster et al., 2013).

[Table 1 about here]

The Australian political science program most highly ranked in the QS World University Rankings is the Australian National University's School of Politics and International Relations (at seventh place in 2015, after Harvard, Princeton, Oxford, LSE, Sciences Po and Cambridge). It is notable that this is only the most highlyranked political science program in Australia but also the one with the greatest emphasis on quantitative approaches (13 out of 25 staff) and the fewest senior women. Elsewhere, relatively few senior political scientists in Australia employ advanced statistical techniques or formal modeling in their work (see Table 1 here and also Sharman and Weller, 2009: 610). However, the pattern in Australian political science departments is changing, with more US-trained younger staff being appointed. In general, a bias in favour of formal approaches amounts to a gender bias as, for example, women have been only five per cent of authors of articles adopting a 'game-theoretic' approach over the past 20 years (West and Jacquet, 2012).

Women's contribution to the discipline is often regarded as 'soft' knowledge—of how political realities and policy problems are discursively framed and reframed; how collective meanings and identities are generated; and how the gendered logic of appropriateness within political institutions includes some and excludes others. The 
contribution of women scholars to explaining the reception and discursive power of the Australian Prime Minister’s 2012 ‘misogyny’ speech is an example of all of this (Johnson 2015a). Yet as international studies have found, gender bias remains in the patterns of scholarly citation, even when the approach and methodology used by the author adheres to the existing hierarchy of knowledge (see Masuoka et al., 2007; Maliniak 2013). In Australia, the referencing practice of the APSA journal (initials rather than names) make it difficult even to identify such gender bias in citations. In general, despite some 40 years of feminist critique, Australian political science exhibits less reflexivity about the relationship between researchers and research subject than cognate social science disciplines. More diverse epistemological standpoints may have been added but the discipline as a whole resists transformation.

\section{New Zealand Compared}

Similarly to Australia, New Zealand has a long history of women’s participation in formal politics. New Zealand women were the first in the world to win the right to vote in 1893 although women were voting in local government earlier than this (from 1867), with New Zealand being the first country in the British Empire to see a woman mayor elected in 1894. It was not uncommon for early feminist activists to view the state as a provider of welfare and social services, and feminist demands on the state continued throughout the $20^{\text {th }}$ century, in a range of forms: indigenous and imported, pragmatic and radical (Curtin, 2015; Sawer, 2003). And, despite a first past the post electoral system, women’s representation reached 21 per cent in the national parliament by 1993 - a comparatively unusual political feat. Since then, two women have become Prime Minister, and three have been appointed Governors’ General. Indeed, the national election of 2011 was the first time since 1993 that neither of the 
two major parties was headed by a woman.

Yet prior to the 1980s, women's absence, as authors and as the subject of political inquiry, was either ignored or considered insignificant within the discipline. This is perhaps surprising given historically, political science in New Zealand was informed by an eclectic range of epistemological, theoretical and methodological traditions. Unlike its United States counterpart, or Australia in more recent years, there has never been a heavy emphasis on large 'n' studies and game theoretic approaches in either the research or teaching of political science. The contents of the journal Political Science, founded in 1948, reflect the development of the discipline. Political theory and the history of political thought had an established presence and this was later supplemented with scholarship representing a variety of subfields: comparative politics, media politics, Māori politics and international relations.

However, many of the early studies of New Zealand politics demonstrated little interest in women as political actors. For example, early key texts that cover New Zealand elections and parties discuss the occupation, age and educational qualifications of candidates, but seldom mention sex (Milne, 1966). Universitysponsored opinion surveys began in 1957, and continued on a small scale until 1966. The results of these surveys indicated that women were more likely to vote National while men were more likely to vote Labour. This difference was not always statistically significant, and the reasons for the difference not systematically investigated. Nevertheless the conclusion was drawn that women were probably more conservative, anxious, and status conscious than their male counterparts, and more likely to draw their political impressions from mass media rather than the 'shop floor' 
(Mitchell, 1969). It was also assumed that women were a majority of floating voters because they were more 'fickle' (Mitchell, 1969: 218). In 1980, Judith Aitken took issue with a number of these depictions, and reminded readers that a women's party had been established to better represent women's issues in the 1978 election (Aitken, 1980). Critiques penned by women on the edges of the discipline were to become a feature of New Zealand politics textbooks for decades to come (Curtin, 2013; Julian, 1985).

Within the journal, articles on or by women were, for a long time, infrequent. As part of the journal's 50 ${ }^{\text {th }}$ Anniversary in 1998, Nicholl and Cousins (1998) published a rich analysis and detailed audit of Political Science and concluded that, in numerical terms, women had been 'treated badly by the journal', particularly prior to the 1980s (Nicholls and Cousins, 1998: 39). Women constituted a small percentage of authors (on average around 6 per cent prior to 1979) and numerous seminal works by and about women were overlooked in the book review section. Indeed, prior to 1988, only 8 books about women had been reviewed by the journal, despite the fact that New Zealand, like elsewhere, had witnessed a plethora of feminist analyses focussing on some element of the 'political' (Curtin, 2015).

Since 1998, however, there has been an incremental increase in the representation of women in the pages of the journal, and from the mid-1990s onwards, citations included first names, making it easier to identify gendered citation patterns. By 2012 the percentage of women authors stood at 26 per cent and women had become increasingly visible as reviewers, with a steady upturn in reviews of books written about feminist/gender politics and of books edited or written by women. However, it is worth noting that 75 per cent (25 out of 33) of these reviews were authored by 
women (Curtin, 2013). Similarly, there have been four special issues of Political Science edited by members of the Women's Caucus: the suffrage celebration issue in 1993 (five of the nine articles authored by women); one on local government in 1999 (five of the seven articles authored by women); one on politics and the media in 2005 (six of the ten articles authored by women); and a women and politics special issue in 2013, where all five articles were written by and about women. The majority of these studies involved qualitative, and interpretive analysis rather than modelling and prediction. $^{4}$

Nicholls and Cousins (1998: 47) argue the historical invisibility of women’s contributions is partly a result of very small numbers of women political scientists, leading to fewer articles submitted by women for consideration. In 1975, one year after the formation of the NZPSA, Juliet Lodge (1976) estimated that women comprised only 6.8 per cent of the discipline and the first woman appointed to the journal’s Editorial Advisory Board was Margaret Clark in 1977. That women were few in number is also evident in the NZPSA newsletters, which suggest it was almost exclusively male political scientists who attended Association Annual General Meetings (NZPSA, 1977; 1982; 1986).

In 1986, a small group of women met for lunch during the NZPSA conference. These were women who felt marginalised within the discipline, partly because they were

\footnotetext{
${ }^{4}$ We are not implying editorial discrimination here and we do not have a gender breakdown of submission rates to the New Zealand journal. It may be that women political scientists are choosing to send their submissions elsewhere, particularly given the current research environment whereby international publications rank more highly than local ones. As already noted, in Australia a gender audit has been included since 2000 as part of the journal editor's annual report - an initiative we would encourage Editorial Boards to pursue.
} 
still so few in number, sometimes with only one per department. Alongside this, several experienced additional isolation by virtue of being located in inter-disciplinary programmes with only one other political scientist. These women were also concerned about the discipline's lack of openness to feminist politics research and teaching. The disestablishment the year before of a position where the female incumbent had taught feminist political theory and gender politics reinforced the sense that a women's network within the Association was necessary for survival. ${ }^{5}$

Learning from its APSA counterpart, and from those involved in the NZ Women's Studies Network, the Women's Caucus was formally established several years later and a Women's Caucus representative provided for on the NZPSA Executive. In 1988, the first issue of the Women Talking Politics Newsletter, edited by dedicated members of the Women's Caucus, came into circulation. While production has sometimes been intermittent, and the title now considered somewhat anachronistic by younger political science scholars, the publication has helped to keep women in the discipline connected professionally over several decades (NZPSA, 2016).

Over time the New Zealand Women's Caucus has helped to build a sense of solidarity and community amongst women political science scholars, with senior scholars 'teaching' more junior women how to negotiate the informal norms and professional practices that came so naturally to many of the men (Hayward, 2008; McLeay in Al

\footnotetext{
${ }^{5}$ Jennifer Curtin would like to thank Bronwyn Hayward and Heather Devere, two of the founding members of what became NZPSA Women's Caucus, for sharing their knowledge and recollections. One year after the feminist politics position was disestablished a new position was created in the same department for a contract lecturer in quantitative methods, advertised in the NZPSA newsletter of July 1986.
} 
Janabi, 2014). ${ }^{6}$ And over the same period the number of women entering the discipline increased incrementally, reaching around 12 per cent by 1996 . By 2012 women comprised 32.6 per cent of political scientists, but there has been no further increase since then (Curtin, 2013; 2016).

[Table 3 about here]

As is the case elsewhere, the overall increase of women in the profession in New Zealand has been a long time coming (Table 3). For example, data from Australia reveal that there has been a seventeen point increase over the past 30 years, most of which occurred between 1980 and the 1990s. This early growth followed by slower progress replicates similar trends in Canada, the United States and the UK. By contrast, New Zealand began from a much lower base in the 1970s and took longer to address the hiring of women in the first 20 years, but since the mid-1990s has made significant progress (Curtin, 2013: 73).

However, an analysis of course offerings at the eight New Zealand universities indicates women remain over-represented amongst those who teach gender, sexuality in both politics and international relations, and under-represented at senior levels. Of the 14 women who have reached senior levels (professor and associate professor), only five are full professors, and comprise only 25 per cent of the professoriate. Moreover, there has never been a female full professor of Politics and International Relations at the University of Auckland, the only New Zealand university ranked in

\footnotetext{
${ }^{6}$ Bronwyn Hayward notes the significance of the mentoring and encouragement provided by Iris Marion Young and Carole Pateman to young women political scientists in New Zealand who were looking to present their work at international conferences.
} 
the top 100 of the QS rankings. The University of Otago and Victoria University of Wellington also feature in the QS World University rankings; currently neither feature a female full professor.

A one-day workshop addressing the status and number of women in the discipline was organised by Kate McMillan and colleagues in 2012. McMillan had attended the Australian equivalent in 2011 and won NZPSA funding to run a New Zealand version. Approximately 45 women attended, including almost all tenured women political scientists as well as some non-tenured staff and postgraduate students. The resulting publication focused on the issue of women's promotion with in-depth discussions of both obstacles and opportunities (Al Janabi et al, 2014). While there is no direct correlation between promotion and research area, the Report on Advancing Women in the Discipline (Al Janabi et al., 2014) indicated that women in the discipline believed there continued to be a marginalisation of feminist perspectives, not helped by the disestablishment of a number of women's studies programmes. To counter this sense of academic isolation, a Gender and Politics Research Network within the Association has been created although it is too soon to assess whether this Network, alongside the Women's Caucus, will be able to resource additional measures of the kind seen in Australia, especially given the small size of the New Zealand Association. In addition, the organisation of such events and networks is seldom valued formally by the discipline it seeks to serve, and those involved often give up precious research time to pursue this kind of activism. Thus while the Women's Caucus has been an important institutional space for women in the discipline in New Zealand, it is unsurprising that its interventions have been less formal and more intermittent than those in Australia. Rather, the Caucus operates as a 
support network and ideas forum for women as critical actors who have taken turns to work towards advancing gender equality in their discipline and their departments.

\section{Indigenous presence in political science}

Both Australia and New Zealand are settler societies with unresolved issues relating to their Indigenous populations. One difference is that these populations are of very different size in the two countries. Aboriginal and Torres Strait Islander people make up 2.5 per cent of the Australian population (2011 census) while in 2012, Māori made up 15.4 per cent of the New Zealand population (Statistics NZ, 2012).

As already noted, until the 1970s, Anglophone political science remained largely preoccupied with majoritarian democracy, resulting, inter alia, in a lack of attention to issues of Indigenous politics and cultural difference. Even in New Zealand, where there have been Māori seats in parliament since 1867, the first article focused on Māori did not appear in the journal Political Science until 1967 and there were no further articles until the mid-1980s (Rowse, 2009: 314). Since then there have been around 15 articles dedicated to Māori politics, although not all are authored by scholars who identify as Māori.

While Indigenous presence in Australian parliaments came much later than in New Zealand, Indigenous political activism was becoming more visible from the 1960s. This was the time of a successful campaign for a Constitutional amendment relating to Aboriginal affairs and a 'freedom bus ride' to draw media attention to racial segregation in outback country towns. By 1972 an Aboriginal flag had been designed and an 'Aboriginal Embassy' set up outside parliament house to advance Aboriginal 
rights and recognition. As noted in a recent survey of Indigenous presence in the journal of the Australian Political Studies Association (Sanders 2015: 679), the first entry of Aboriginal issues into Politics was a brief book review in 1968 and a review article by an Aboriginal poet in 1970 .

The first full articles on Indigenous issues followed in the 1970s, including a brief one by an Aboriginal candidate in the 1972 federal election. The interest in including Aboriginal perspectives in the journal, like the interest in including feminist perspectives, was due to the journal's editor, Henry Mayer. His openness to issues of racial (and gender) identity has been linked in part to his personal history as a Jewish refugee from Nazi Europe (Rowse 2009: 314-316). It has also been noted that it was only in the 1970s that Anglophone political science began seriously considering alternatives to majoritarian democracy, including Arend Lijphart's concept of consociational democracy (Rowse: 2009: 315).

Issues of political representation and electoral institutions, changing paradigms of Aboriginal governance and self-determination, the impact of neoliberalism, and discursive issues around reconciliation, have now been taken up in Australian political science, particularly by female scholars. In 2009 the joint winner of the first Henry Mayer book prize for Australian politics was a book on Indigenous politics, by a non-Indigenous woman political scientist (Maddison 2009).

As noted by Will Sanders, in the first 25 years of the APSA journal there were only ten articles on Indigenous issues, followed by ten in the 1990s and then 24 between 2000 and 2014 (Sanders 2015). Despite this increased interest, Indigenous issues 
feature much less strongly in political science than in anthropology and law (particularly in relation to native title and human rights issues). And Aboriginal scholars are notably absent from the political science profession, unlike, for example, their presence in interdisciplinary Aboriginal Studies Centres. In terms of the APSA journal, Māori authors are better represented than Aboriginal authors and there has not yet been a full-length article by an Aboriginal author (Sanders 2015: 692).

As noted above, it is not unusual to find topics that might otherwise 'count' as feminist politics scholarship being undertaken by scholars in fields or disciplines that are more open to the idea of gender as a significant social construct and organising principle. In both Australia and New Zealand something similar applies in terms of indigeneity and ethnicity. Thus, while Political Science has featured articles on and by Māori, as have key text books, the presence of Māori academics within Politics departments is minimal. While no systematic diversity survey has been undertaken of either Australian or New Zealand political science to date, ${ }^{7}$ all the evidence suggests that those who identify as Indigenous comprise less than 1 per cent of politics department staff in New Zealand, and 0 per cent in Australia.

There is a larger number of Māori political scientists located in Māori Studies departments and other schools and faculties, such as education, suggesting perhaps that politics departments may be culturally chilly for Indigenous peoples.

Nevertheless many of these scholars are members of the NZPSA and there is a Māori

\footnotetext{
${ }^{7}$ The very much larger American Political Science Association has relatively good data on the slow increase in African American, Latina/o and Asian Pacific Islander faculty in the USA and has also had committees on the Status of Blacks in the Profession since 1969, on Latinos y Latinas since 1970, on LGBT since 1992 and Asian Pacific Americans since 2003 (American Political Science Association 2011: 9).
} 
representative on the Association executive, in contrast to the absence of Aboriginal scholars from APSA or its executive. Most NZPSA conferences include at least two panels on Indigenous politics and policy and this is also true of Australian conferences, but in the latter case these are presented by non-Indigenous scholars.

In terms of intersectionality, there has been a range of scholarship on feminist theory and ideas in New Zealand from diverse perspectives, including by and about Māori, indigenous feminism and the challenges offered by postcolonial feminists to 'western' liberal and radical feminist ideas, however this work seldom appears in traditional political science journals and texts (for a fuller discussion see Curtin 2015; see also Tan, 2015).

An historical ‘word cloud’ analysis undertaken by Tan et al (2009) emphasises graphically the continued focus of the Political Science journal on traditional political science topics. Elections, parties, voters, are represented in large bold type, and while the term Māori features in the three clouds covering three decades, its font size is smaller indicating its more marginal status. However, gender or women is even less common and the term 'intersectionality' does not feature at all. Interestingly, 'Waitangi' does appear in these clouds, and a regular stream of reviews on books covering topics related to Māori politics appear in the journal, including the globally recognised text Decolonising Methodologies by Linda Tuhiwhai Smith (1999). From this we might conclude that the reinstatement of the Treaty of Waitangi (originally signed between Māori and the Crown in 1840) as one of New Zealand’s founding governing documents, and the establishment of the Waitangi Tribunal to consider 
land claims and other grievances, stimulated a growth of research into Māori politics and governance from the 1980s, by Māori and non-Māori scholars.

In 2015, the NZPSA conference theme was 'Disrupting the Discipline’ and included a series of panels dedicated to 'Decolonising the Discipline’. Maria Bargh’s presentation focused on why and how teachers and students of political science in New Zealand should decolonise. Her summary, published in a recent issue of Women Talking Politics (2015: 10-11), highlights how existing practices and hierarchical power structures have reinforced a lack of awareness of the Māori aspects of New Zealand's political history, and obscured corresponding legal obligations, connected to the Treaty. Bargh's analysis, and a number of other papers presented at the conference (NZPSA, 2015) demonstrate that, while the under-representation of Indigenous peoples within political science departments is problematic, there is much that Pākehā (non-Māori) academics can do to undermine continued colonial practices in public institutions such as universities and government.

\section{Conclusion}

Feminist organisational activism within the Australian Political Studies Association has become institutionalised over time. Success has been variable: more with respect to the presence of women in the discipline and to the inclusion of articles and chapters about women, gender and sexuality; less when it comes to gender mainstreaming the curriculum and finding feminist scholars cited within 'mainstream' political science. Moreover any success has remained dependent on iterative activity such as surveys that draw attention to the 'leaky pipeline' and the fact that the normative political scientist is still likely to have masculine characteristics such as uninterrupted careers 
and unimpeded mobility (Al Janabi et al., 2014; Cowden et al., 2012).

However, the commitment of younger as well as senior scholars to the role of the APSA Women's Caucus remains strong, evidenced in part by its Facebook presence. Because of the small size of the discipline in New Zealand, the New Zealand Women's Caucus has been even more dependent on the activities of critical actors and strong succession planning, with a number of female NZPSA presidents elected over the past 15 years. The overlap of membership between the Australian and New Zealand political studies associations has facilitated policy learning and exchange, although there are some differences in women's Caucus repertoire - for example, the Women Talking Politics newsletter in New Zealand as compared to the Australian Facebook page.

Without this sustained organising over time, and the support it has provided for greater diversity in the discipline, it is unlikely that these two regional professions would pay as much attention to gender or include as many women as they do. The presence of women as political science staff is still far from reflecting their presence among PhD graduands, let alone the gender balance of undergraduate students in the discipline. $^{8}$

Feminist organising within Australian and New Zealand political science has contributed to a discipline more inclusive of diversity but in both countries the study of Indigenous politics and policy issues is more likely to take place in

\footnotetext{
${ }^{8}$ In comparative terms, New Zealand is less successful in attracting female doctoral candidates compared to the United Kingdom and sits far behind Australia. An email and website survey conducted in 2012 suggests women comprised 37\% of $\mathrm{PhD}$ scholars in New Zealand (Curtin, 2013: 70).
} 
interdisciplinary centres than in politics departments. We suggest this may be attributable to two factors: the role of new forms of research governance in reinforcing disciplinary boundaries, and/or a chilly cultural climate, where international experience and global reach is valued more highly than local qualifications and cultural competence or desire for decolonised methodologies.

\section{Acknowledgements}

The authors thank Richard Reid for assistance with data collection and Carol Johnson, Jacqui True, Heather Devere, Bronwyn Hayward and Kate McMillan for their comments. The European Political Science reviewers provided very constructive criticism, which helped strengthen the article.

\section{References}

Aitken, J. (1980), ‘Women in New Zealand Politics', in H. Penniman (ed) New Zealand at the Polls. The General Election of 1978, Washington DC: American Enterprise Institute for Public Policy Research, pp. 197-214.

Al Janabi, A., McMillan, K. and Lam, C. (2014), Advancing the Status of Women in Politics and International Relations in New Zealand, available at http://nzpsa.com/womens-caucus, accessed 10 February 2016.

American Political Science Association (2011), Political Science in the $21^{\text {st }}$ Century: Report of the Task Force on Political Science in the $21^{\text {st }}$ Century, available at: http://www.apsanet.org/portals/54/Files/Task\%20Force\%20Reports/TF_21st\%20Cent ury_AllPgs_webres90.pdf, accessed 12 December 2015.

Arashiro, Z. and Barahon, M. (2015), Women in Academia Crossing North-South Borders: Gender, Race, and Displacement, Lanham MD: Lexington Books.

Bargh, M. (2015), 'Contexts for decolonizing the discipline of Political Science in Aotearoa-New Zealand', Women Talking Politics, Issue 1, 2015, available at http://nzpsa.com/resources/Documents/WTP/december\%202015.pdf , accessed 10 March 2016.

Brown, M. C. (1983), National Health Insurance in Canada and Australia: A comparative political economy analysis, Canberra: Australian National University.

Chappell, L. and Brennan, D. (2009), 'Women and Gender’, in R.A.W. Rhodes (ed) 
The Australian Study of Politics, Basingstoke: Palgrave Macmillan, pp. 338-346.

Cowden, M., McLaren, K., Plumb, A. and Sawer, M. (2012), ‘Women’s

Advancement in Australian Political Science: Workshop Report., available at:

https://womeninpoliticalscience.files.wordpress.com/2012/01/womens-advancementin-australian-political-science-report1.pdf, accessed 12 December 2015.

Curtin, J. (2013), 'Women and Political Science in New Zealand: The state of the discipline’, Political Science, 65 (1): 63-83.

Curtin, J. (2015), 'Feminist contributions to New Zealand political science, Women's Studies Journal 29(1): 4-20.

Curtin, J. (2016), 'Gender Mainstreaming and Political Science Teaching in New Zealand: Still a work in progress', in E. Levintova and A. Staudinger (eds) Gender in Teaching and Learning Political Science, Indiana University Press, forthcoming.

Curtin, J., Chappell, L. and Hill, L. (1999), 'Gender Audit of the Australian Journal of Political Science 1979-1998: A Preliminary Report', in J. Brookfield (ed.) Proceedings of the 1999 Conference of the Australasian Political Studies Association, September 26-29, University of Sydney, 155-8.

Foster, E., Kerr, P., Hopkins, A., Byrne, C. and Ahall, L. (2013), 'The Personal is Not Political: At Least Not in the UK's top Politics and IR Departments', British Journal of Politics and International Relations 15(4): 566-585.

Goot, M. and Reid, E. (1975), Women and voting studies: Mindless matrons or sexist scientism, London: Sage.

Hayward, B. (2008), 'Let's Talk about the Weather: Decentering Democratic Debate About Climate Change’, Hypatia, 23(3), 79-98.

Johnson, C. (2014), 'Hard heads and soft hearts: The gendering of Australian political science’, Australian Feminist Studies 29(80): 121-136.

Johnson, C. (2015a), 'Playing the Gender Card: The Uses and Abuses of Gender in Australian Politics’, Politics \& Gender 11(2): 291-319.

Johnson, C. (2015b), 'Women, gender and feminism in the Australian Journal of Political Science: A review’ 50(4): 695-706.

Julian R. (1985), ‘Women: How Significant a Force?’, in H. Gold (ed.) New Zealand Politics in Perspective, $1^{\text {st }}$ edn, Auckland: Longman Paul.

Lodge, J. (1976), 'New Zealand Women Academics: Some Observations on their Status, Aspirations, and Professional Advancement', Political Science, 28(1): 23-40.

McAllister, I. (2006), Australian Journal of Political Science Report to the 2006 Annual General Meeting of the Australasian Political Studies Association. 
Maddison, S. (2009), Black Politics: Inside the complexity of Aboriginal political culture, Sydney: Allen \& Unwin.

Maliniak, D., Powers, R. and Walter, B.F. (2013), 'The Gender Citation Gap in International Relations', International Organization, DOI:

10.1017/S0020818313000209

Masuoka, N., Grofman, B. and Feld, S.L. (2007), 'The Political Science 400: A 20Year Update’, PS: Political Science and Politics 40 (1): 133-145.

Milne, R.S. (1966), Political Parties in New Zealand, Oxford: Clarendon Press.

Mitchell, A. V. (1969), Politics and People in New Zealand, Christchurch:

Whitcombe and Tombs.

Nicholl, R. and Cousins, M. (1998), 'Brief Encounter? Women and Political Science. The First Fifty Years’, Political Science 50(1): 38-52.

NZPSA (1977), 'Newsletter, New Zealand Political Studies Association’3(1), Winter, available at http://nzpsa.memberlodge.org/resources/Documents/Newsletters/1977\%20Winter.pdf , accessed 10 March 2016.

NZPSA (1982), 'POLS. The New Zealand Political Studies Association Newsletter' 7(2), August, available at http://nzpsa.memberlodge.org/resources/Documents/Newsletters/1982\%20August.pdf accessed 10 March 2016.

NZPSA (1986), 'POLS. The New Zealand Political Studies Association Newsletter', Volume 11, Number 2, July, available at http://nzpsa.memberlodge.org/resources/Documents/Newsletters/1986\%20July.pdf accessed 10 March 2016.

NZPSA (2015), 'Disrupting the Discipline’, NZPSA Conference Programme, Massey University, available at http://nzpsa.com/resources/Documents/NZPSA\%20Conference\%20Docs/NZPSA\%20 Conference\%20Programme_FInal_2015.pdf, accessed 10 March 2016.

Pateman, C. (1982), 'Presidential address: Women and political studies', Politics 17(1): 1-6.

Rowse, T. (2009), 'Indigenous Politics', in R.A.W. Rhodes (ed) The Australian Study of Politics, Basingstoke: Palgrave Macmillan, pp. 314-337.

Sanders, W. (2015), 'Writing on Indigenous Politics: The journal's first fifty years', Australian Journal of Political Science 50(4): 679-694.

Sawer, M. (1980), 'Women in the Political Science Profession', Supplement to Politics 15(1): 1-4. 
Sawer, M. (2003), The Ethical State? Social Liberalism in Australia, Melbourne: Melbourne University Press.

Sawer, M. (2004), 'The impact of feminist scholarship on Australian Political Science', Australian Journal of Political Science 39(3): 553-566.

Sawer, M. (2014), 'Feminist Political Science and Feminist Politics', Australian Feminist Studies 29(80): 137-147.

Sharman, J.C. and Weller, P. (2009), 'Where is the Quality? Political Science Scholarship in Australia’, Australian Journal of Political Science 44(4): 597-612.

Statistics NZ (2012), 'Māori population grows and more live longer', Press Release, available at http://www.stats.govt.nz/tools_and_services/media-centre/additionalreleases/maori-population-estimates-15-nov-2012.aspx, accessed 10 March 2016.

Summers, A. (1975; 1994; 2002), Damned Whores and God's Police, Ringwood: Penguin.

Tan, A., Buck, J. and Schrader, E. (2009). 'Portraits of New Zealand Political Science, 1980-2008: A Picture is Worth Eighty Words’, Political Science 61 (1): 8183

Tan, L. (ed.) (2015), Women Talking Politics, Issue 1, available at http://nzpsa.com/resources/Documents/WTP/december\%202015.pdf , accessed 10 March 2016.

True, J. (2013), The Political Economy of Violence against Women, Oxford: Oxford University Press.

West, J. and Jacquet, J. (2012), 'Women as academic authors, 1665-2010', The Chronicle of Higher Education, Special Report, available at http://chronicle.com/article/Women-as-Academic-Authors/135192/, accessed 7 March 2016.

Wilson, H. (2006), Thirty years of MIA: A commemorative editorial. MIA 119(May): 3-20. 
Table 1. Occupants of Australian chairs of political science and international relations, February 2016, by gender and research approaches*

\begin{tabular}{llll}
\hline Political Science & Quantitative/Formal & Qualitative & Total \\
\hline Male chairs & 6 & 42 & 48 \\
Female chairs & 2 & 16 & 18 \\
Total PolSci & 8 & 58 & 66 (female 27\%) \\
\hline & & & \\
Int. Relations & & 20 & 20 \\
\hline Male chairs & 0 & 9 & 9 \\
Female chairs & 0 & 29 & 29 (female 31\%) \\
Total IR & 0 & & \\
\hline
\end{tabular}

* This includes full professors only, drawn from university websites and (unlike Table 2) does not include associate professors. It does not include emeritus or adjunct appointments. 'Quantitative' includes use of advanced statistical techniques, formal modeling and rational choice. Qualitative includes institutional and discursive analysis and political economy. A few of the political science and international relations chairs had some quantitative elements in their work, but this was not regarded as the main element of their approach.

Table 2: New Zealand political scientists by position and gender, 2016*

\begin{tabular}{llll|lll}
\hline & \multicolumn{3}{c}{ Professor } & \multicolumn{3}{c}{ Associate Professor } \\
\hline & Female & Male & Total & Female & Male & Total \\
$\%$ & $25 \%$ & $75 \%$ & $100 \%$ & $45 \%$ & $55 \%$ & $100 \%$ \\
$\mathrm{~N}$ & $(5)$ & $(15)$ & $(20)$ & $(9)$ & $(11)$ & $(20)$ \\
\hline
\end{tabular}

* The professor/associate professor categories are drawn from University websites. Every attempt has been made to count political scientists who are located in interdisciplinary programs, research centres and Māori Studies departments. The figures included here do not count new staff, those promoted after April 2016, or emeritus or adjunct appointments.

Table 3: Proportion of women in the discipline by country (1975-2012)

\begin{tabular}{l|c|c|c}
\hline Country & $\begin{array}{c}\text { \% women } \\
\text { 1975-80 }\end{array}$ & $\begin{array}{c}\text { \% women } \\
\text { 1996-02 }\end{array}$ & $\begin{array}{c}\text { \% women } \\
\text { 2010-12 }\end{array}$ \\
\hline NZ & 6.8 & 12.5 & 32.6 \\
Australia & 11 & 29.7 & 28 \\
Canada & 11 & 23.6 & 28 \\
UK & 10 & 24 & 31 \\
USA & 10.3 & 24 & 35.9 \\
\hline
\end{tabular}

Note: the span of years is necessary because not all Status of Women reports were conducted in the same year across countries; the aim here is to give a snapshot of periods over time (original table in Curtin, 2013: 72). 